\title{
Characterization of the $5-\mathrm{HT}_{4}$ receptor mediating tachycardia in piglet isolated right atrium
}

\author{
Andrew D. Medhurst \& ${ }^{1 *}$ Alberto J. Kaumann
}

SmithKline Beecham Pharmaceuticals, Coldharbour Road, The Pinnacles, Harlow, Essex CM19 5AD \& *Clinical Pharmacology Unit, University of Cambridge, Addenbrooke's Hospital, Hills Road, Cambridge CB2 2QQ

1 In order to explore whether 5-HT 4 receptor subtypes exist, we have characterized further the 5-HT receptor that mediates tachycardia in the piglet isolated right atrium. All experiments were carried out in the presence of propranolol $(400 \mathrm{nM})$ and cocaine $(6 \mu \mathrm{M})$. We used tryptamine derivatives, substituted benzamides and benzimidazolone derivatives as pharmacological tools.

2 Tachycardia responses to 5-hydroxytryptamine (5-HT) were mimicked by other tryptamine derivatives with the following order of potency: 5-HT $>5$-methoxytryptamine $>\alpha$-methyl-5-HT $=$ bufotenine $>5$-carboxamidotryptamine $=$ tryptamine (after treatment with pargyline) $>5$-methoxy- $N, N$ dimethyltryptamine $>2$-methyl-5-HT.

3 The substituted benzamides were all partial agonists relative to 5-HT except ( - )-zacopride which was a full agonist. The stimulant potency order was renzapride $>$ cisapride $=(-)$-zacopride $>$ metoclopramide $>(+)$-zacopride.

4 The benzimidazolone derivatives had contrasting effects. BIMU 8 (endo-N-(8-methyl-8azabicyclo[3.2.1]oct-3-yl)-2,3-dihydro-(1-methyl(ethyl-2-oxo-1H-benzimidazole-1-carboxamide hydrochloride) was a full agonist relative to 5-HT whilst BIMU 1 (endo-N-(8-methyl-8-azabicyclo[3.2.1]oct-3-yl)2,3-dihydro-3-ethyl-2-oxo-1H-benzimidazole-1-carboxamide hydrochloride) was a partial agonist with low intrinsic activity compared to 5-HT but had similar potency. We estimated a $\mathrm{p} K_{\mathrm{B}}$ of 7.9 for BIMU 1 antagonism of 5-HT-induced tachycardia. DAU 6215 (N-endo-8-methyl-8-azabicyclo[3.2.1]-oct-3-yl)-2,3dihydro-2-oxo-1H-benzimidazole-1-carboxamide, hydrochloride) had no chronotropic activity and was found to be a simple competitive antagonist with a $\mathrm{p} K_{\mathrm{B}}$ of 7.1

5 SB 203186 (1-piperidinyl)ethyl 1H-indole 3-carboxylate) was a potent antagonist with a p $K_{\mathrm{B}}$ of 8.3. The affinity of SB 203186 was approximately 20 times higher than that of tropisetron (ICS 205-930; $\left.\mathrm{p} K_{\mathrm{B}}=6.9\right)$ and DAU $6215\left(\mathrm{p} K_{\mathrm{B}}=7.0\right)$. GR113808 (([1-[2-[methylsulphonyl amino]ethyl]-4-piperidinyl] methyl 1-methyl-1H-indole-3-carboxylate) and SDZ 205-557 ((2-diethylaminoethyl)2-methoxy-4-amino5-chloro-benzoate) also antagonized 5-HT-induced tachycardia but not by simple competitive blockade. 6 The sinoatrial $5-\mathrm{HT}_{4}$ receptor in the piglet has a pharmacological profile that correlates well with 5- $\mathrm{HT}_{4}$ receptors characterized in rat oesophagus, guinea-pig ileum and colon, mouse embryonic colliculi neurones and human atrium.

Keywords: 5- $\mathrm{HT}_{4}$ receptors; piglet right atrium; tachycardia; tryptamines; benzamides; benzimidazolones; SB 203186; SDZ 205-557; DAU 6215; GR113808

\section{Introduction}

$5-\mathrm{HT}_{4}$ receptors have been identified in a number of tissues including the brain, gastrointestinal tract and the heart (atrium and sinoatrial node). They were first described in primary cultures of mouse embryonic colliculi neurones (Dumuis et al., 1988) and in guinea-pig hippocampal membranes (Shenker et al., 1987; Dumuis et al., 1988) where they mediate 5-hydroxytryptamine (5-HT)-induced stimulation of adenylyl cyclase activity.

Gastrointestinal 5- $\mathrm{HT}_{4}$ receptors are present in guinea-pig stomach (Buchheit \& Bertholet, 1992), ileum (Craig \& Clarke, 1990; Eglen et al., 1990) and colon (Elswood et al., 1991; Wardle \& Sanger, 1992) where they mediate contractile responses to 5-HT and/or increases in electrically-evoked twitch contractions induced by 5-HT. Stimulation of 5-HT receptors in rat oesophagus causes relaxation (Baxter et al., 1991; Reeves et al., 1991) which occurs via adenylyl cyclase activation (Ford et al., 1992).

$5-\mathrm{HT}_{4}$ receptors in the heart mediate positive chronotropic effects of 5-HT in adult and newborn pigs (Villalon et al., 1990; 1991; Kaumann, 1990) as well as mediating 5-HTinduced increases in contractile force, adenosine $3^{\prime}: 5^{\prime}$-cyclic monophosphate (cyclic AMP) content and cyclic AMP-

\footnotetext{
${ }^{1}$ Author for correspondence.
}

dependent protein kinase stimulation in paced human right and left atrial preparations (Kaumann et al., 1990; 1991a; Sanders \& Kaumann, 1992). 5-HT 4 receptors also mediate positive inotropic effects and increases in cyclic AMP by 5-HT in piglet left atria (Kaumann et al., 1991b).

Three families of compounds have agonist activity at some or all of the 5- $\mathrm{HT}_{4}$ receptors described. 5-HT and other tryptamines including 5-methoxytryptamine (5-MeOT) often act as full agonists (Dumuis et al., 1988; Craig \& Clarke, 1990) whilst benzamide derivatives like cisapride and renzapride are sometimes full agonists (Dumuis et al., 1989) but usually partial agonists at 5-HT 4 receptors (Kaumann, 1990; Kaumann et al., 1991a).

Recently azabicycloalkyl benzimidazolone derivatives (Turconi et al., 1991) have also been shown to be potent full or

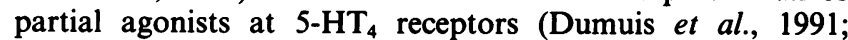
Baxter \& Clarke, 1992).

Tropisetron (ICS 205-930) has been extensively used as an antagonist of $5-\mathrm{HT}_{4}$ receptors despite its relatively low affinity and poor selectivity (reviewed by Bockaert et al., 1992a). Several compounds have recently been reported to be more potent and selective $5-\mathrm{HT}_{4}$ antagonists than tropisetron, including SDZ 205-557 ((2-diethylaminoethyl)2methoxy-4-amino-5-chloro-benzoate) (Buchheit et al., 1991; 1992). DAU 6215 (N-(endo-8-methyl-8-azabicyclo[3.2.1]-oct- 
3-yl)-2,3-dihydro-2-oxo-1H-benzimidazole-1-carboxamide, hydrochloride) (Turconi et al., 1991; Dumuis et al., 1991; Baxter \& Clarke, 1992), SB 203186 ((1-piperidinyl)ethyl 1Hindole 3-carboxylate) (Kaumann et al., 1992; Parker et al., 1993) and GR113808 ([1-[2-[methylsulphonyl amino]ethyl]-4piperidinyl]methyl 1-methyl-1H-indole-3-carboxylate (Grossman et al., 1993).

The present study was designed to characterize more fully the 5-HT 4 receptor described by Kaumann (1990) which mediates 5-HT-induced tachycardia in spontaneously beating right atria of newborn piglets. Using the various agonist and antagonists described above, we have compared the pharmacological properties of $5-\mathrm{HT}_{4}$ receptors in porcine sinoatrial node with those described for rat oesophagus (Baxter et al., 1991; Baxter \& Clarke, 1992), guinea-pig ileum and colon (Craig \& Clarke, 1990; Eglen et al., 1990; Wardle \& Sanger, 1992), mouse embryonic colliculi neurones (Dumuis et al., $1988 ; 1989 ; 1991$ ) and human atrium (Kaumann et al., 1990; 1991a; Sanders \& Kaumann, 1992).

\section{Methods}

Male and female piglets (2-5 days old) were obtained from local farms and anaesthetized with halothane. The heart was excised and immediately washed free of blood with warm solution containing (mM): $\mathrm{Na}^{+} 125, \mathrm{~K}^{+} 5, \mathrm{Ca}^{2+} 2.25, \mathrm{Mg}^{2+}$ $0.5, \mathrm{Cl}^{-}$98.5, $\mathrm{SO}_{4}^{2-} 0.5, \mathrm{HCO}_{3}-34, \mathrm{HPO}_{4}^{2-} 1$, EDTA 0.04 , and aerated with $95 \% \mathrm{O}_{2}$ and $5 \% \mathrm{CO}_{2}$. The right atrium was dissected in warm solution and mounted in a $50 \mathrm{ml}$ organ bath using the apparatus described by Blinks (1965). The organ bath contained the solution described above at $37^{\circ} \mathrm{C}$ supplemented with $(\mathrm{mM}): \mathrm{Na}^{+} 15$, fumarate 5 , pyruvate 5 , L-glutamate 5 , glucose 10 and continuously gassed with $95 \%$ $\mathrm{O}_{2}$ and $5 \% \quad \mathrm{CO}_{2}$ for the duration of the experiment. The water used throughout was deionised and twice distilled in glass.

Each spontaneously beating right atrium was suspended at a resting length just sufficient for measurable development of force. Care was taken not to overstretch the atrium since tachycardia could result (Blinks, 1956). The atrium was attached to a Swema SG4-45 strain gauge transducer by means of a stainless steel wire and force recorded on a Watanabe polygraph.

All experiments were carried out in the presence of $400 \mathrm{nM}$ ( \pm )-propranolol (to avoid possible indirect $\beta$-adrenoceptormediated effects due to noradrenaline; Kaumann, 1990), $6 \mu \mathrm{M}$ cocaine (to block neuronal uptake; Kaumann et al., 1990) and $200 \mu \mathrm{M}$ ascorbate (to decrease oxidation of 5-HT). In some experiments atria were pretreated with pargyline $(50 \mu \mathrm{M})$ for half an hour followed by washout to inhibit irreversibly monoamine oxidase (MAO).

A single cumulative concentration-effect curve was determined on each atrium by sequential addition of tryptamines, benzamides or benzimidazolones to the bath in amounts that increased the total concentration in steps of $0.5 \mathrm{log}$ unit. Enough time was allowed for each effect to reach equilibrium. Control 5-HT curves were constructed in parallel tissues. In some experiments a concentration-effect curve for a partial agonist was followed by one for 5-HT in the presence of the highest concentration of the partial agonist. To assess the intrinsic activity of other agonists with respect to $5-\mathrm{HT}, 600 \mu \mathrm{M} 5-\mathrm{HT}$ was administered after completion of a concentration-effect curve to an agonist (and in the presence of the latter).

To study the effects of antagonists separate atria were incubated with tropisetron, DAU 6215, SDZ 205-557, GR113808 or SB 203186 for at least $60 \mathrm{~min}$ before determination of the agonist concentration-effect curve. Control 5-HT curves were determined in other tissues in parallel.

All experiments were terminated by the addition of a saturating concentration of $(-)$-isoprenaline $(200 \mu \mathrm{M})$ still in the presence of test agonist or antagonist, and 5-HT
$(600 \mu \mathrm{M})$. This $(-)$-isoprenaline concentration was calculated to surmount completely the antagonism by $( \pm)$-propranolol (Kaumann et al., 1980).

The positive chronotropic effects of drugs were expressed as a percentage of the total increase in beating rate caused by agonist or agonist combination plus $200 \mu \mathrm{M}(-)$-isoprenaline ( $\triangle$ HR \% $\triangle$ Iso). This procedure provided an independent way of estimating maximum increases in beating rates induced by 5-HT, other agonists, and partial agonists (Kaumann, 1990).

\section{Agonist potency}

The ability of agonists to induce tachycardia was expressed in absolute terms as $\mathrm{pEC}_{50}$ values relative to their individual maxima $\left(\mathrm{pEC}_{50}=-\log \mathrm{EC}_{50}\right.$ concentration of agonist required to produce half-maximal effect).

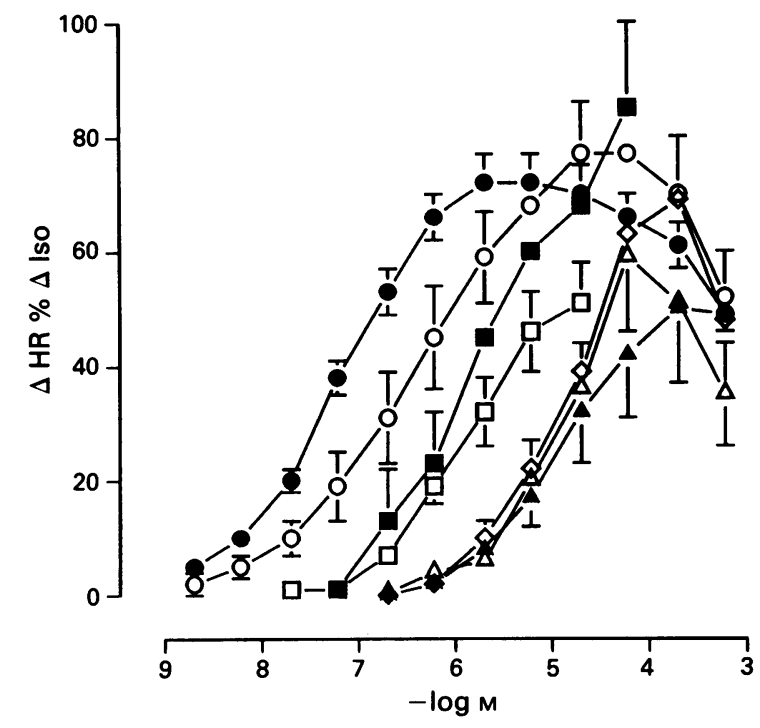

Figure 1 Concentration-effect curves to 5-HT $(\Theta, n=33)$, 5-MeOT $(\mathrm{O}, n=7), \alpha$-methyl-5-HT $(\square, n=7)$, bufotenine ( $\square, n=4)$, tryptamine $(\diamond, n=7), 5-\mathrm{MeO}-N, N$-DMT $(\Delta, n=4)$ and 5-CT $(\Delta$, $n=4)$ in piglet right atrium. Data are means \pm s.e.mean. The chronotropic effects of agonists are expressed as a percentage of the increase in beating rate caused by agonist plus $200 \mu \mathrm{M}$ isoprenaline ( $\Delta$ HR \% $\Delta$ Iso). 5-CT data from Kaumann (1990). For abbreviations, see text.

Table 1 Agonist potency and intrinsic activity in piglet right atrium

\begin{tabular}{lllr}
\hline Agonist & $p E C_{50^{a}}$ & $\begin{array}{c}\text { Intrinsic } \\
\text { activity }\end{array}$ & $\mathrm{n}$ \\
& $7.13 \pm 0.1$ & 1.0 & 33 \\
5-HT & $6.36 \pm 0.3$ & 1.07 & 7 \\
5-MeOT & $5.90 \pm 0.1$ & 1.18 & 7 \\
Bufotenine & $5.95 \pm 0.04$ & 0.71 & 4 \\
Tryptamine & $4.87 \pm 0.14$ & 0.96 & 7 \\
5-MeO- $N, N$-DMT & $4.69 \pm 0.21$ & 0.82 & 4 \\
5-CT & $4.89 \pm 0.13$ & 0.69 & 4 \\
Renzapride & $6.70 \pm 0.11^{*}$ & 0.69 & 4 \\
Cisapride & $6.44 \pm 0.1^{*}$ & 0.39 & 4 \\
(-)-Zacopride & $6.41 \pm 0.12$ & 0.94 & 6 \\
(+)-Zacopride & $5.27 \pm 0.24$ & 0.33 & 4 \\
Metoclopramide & $5.73 \pm 0.1$ & 0.29 & 4 \\
BIMU 8 & $6.70 \pm 0.12$ & 0.89 & 8 \\
BIMU 1 & $7.13 \pm 0.05$ & 0.39 & 6
\end{tabular}

${ }^{\mathrm{a}} \mathrm{pE}_{50}=-\log$ concentration of agonist required to produce $50 \%$ of the maximum increase in heart rate; mean \pm s.e.mean.

*Data from Kaumann (1990). For abbreviations, see text. 


\section{Drug-receptor constants}

The equilibrium dissociation constant $K_{\mathrm{B}}\left(-\log K_{\mathrm{B}}=\mathrm{p} K_{\mathrm{B}}\right)$ for the antagonist-5- $-\mathrm{HT}_{4}$ receptor complex was calculated from

$$
\mathrm{p} K_{\mathrm{B}}=\log (\mathrm{CR}-1)-\log [\mathrm{B}]
$$

where $\mathrm{CR}$ is the concentration-ratio of agonist used in the presence and absence of antagonist (B). The assumption of simple competition (i.e. slope of unity) between antagonist and agonist for $5-\mathrm{HT}_{4}$ receptors was checked with a Schild plot (Arunlakshana \& Schild, 1959).

The equilibrium dissociation constant $K \mathrm{p}(-\log K \mathrm{p}=$ $\mathrm{p} K \mathrm{p}$ ) was estimated by the method of Marano \& Kaumann (1976), and Lemoine \& Kaumann (1982). Kp was estimated from the slope of a weighted plot which relates equieffective concentrations of 5-HT in the absence $\left(A_{2}\right)$ and presence $\left(A_{3}\right)$

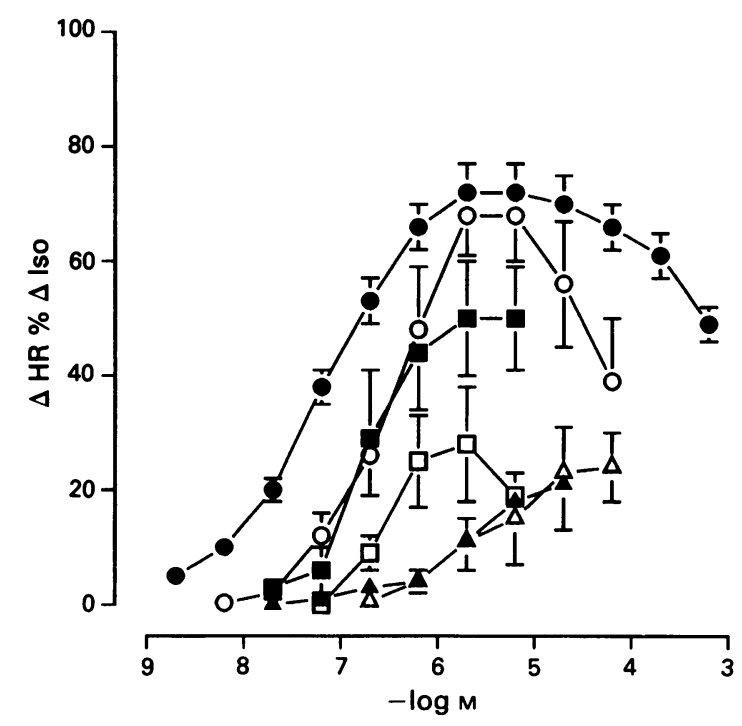

Figure 2 Concentration-effect curves to 5-HT (O, $n=33$ ), $(-)$-zacopride $(O, n=6)$, renzapride $(\square, n=4)$, cisapride $(\square$, $n=4),(+)$-zacopride $(\Delta, n=4)$ and metoclopramide $(\Delta, n=4)$ in piglet right atrium. Data are means \pm s.e.mean. The chronotropic effects are expressed as a percentage of the increase in beating rate caused by agonist plus $200 \mu \mathrm{M}$ isoprenaline ( $\Delta \mathrm{HR} \% \Delta$ Iso). Renzapride and cisapride data from Kaumann (1990).

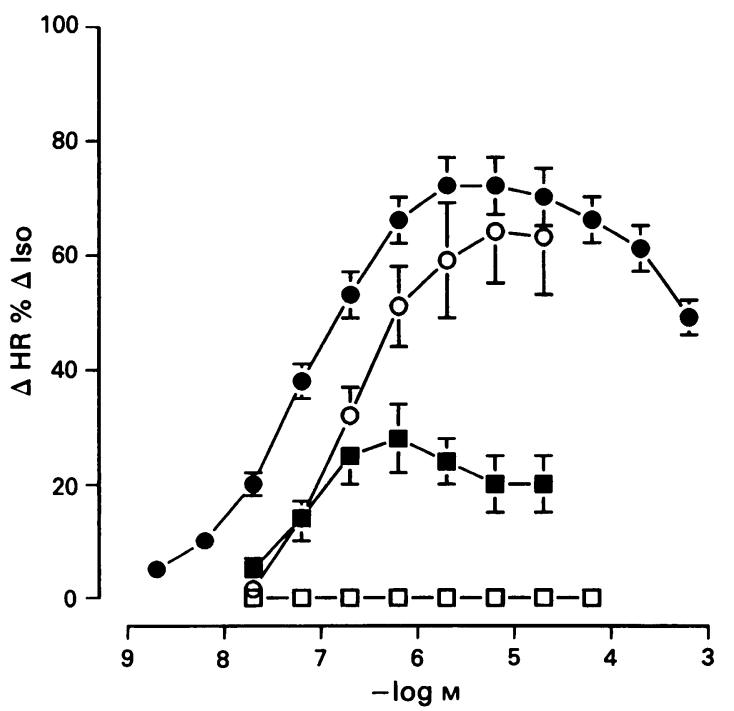

Figure 3 Concentration-effect curves to 5-HT (,$n=33)$, BIMU 8 $(\mathrm{O}, n=8)$, BIMU $1(\square, n=4)$ and DAU $6215(\square, n=4)$ in piglet right atrium. Data are means \pm s.e.mean. The chronotropic effects are expressed as a percentage of the increase in beating rate caused by agonist plus $200 \mu \mathrm{M}$ isoprenaline ( $\Delta \mathrm{HR} \% \Delta$ Iso). For abbreviations, see text. of a partial agonist $P, A_{2}=i+m A_{3}$, where $i$ is the ordinate intercept. The slope $m$ of the regression equals $m=1-y p$, where the fractional $5-\mathrm{HT}_{4}$ receptor occupancy yp by the partial agonist $\mathrm{P}$ is given by $[\mathrm{P}] /([\mathrm{P}]+K \mathrm{p})$. p $K \mathrm{p}$ was calculated from

$$
\log (1 / \mathrm{m}-1)=\log [\mathrm{P}]-\log K \mathrm{p}
$$

For simple competition between a 5-HT molecule and a partial agonist molecule for one $5-\mathrm{HT}_{4}$ receptor molecule, equation (2) has a slope of one, as in the Schild equation.

\section{Drugs}

5-Hydroxytryptamine hydrochloride (5-HT), 5-methoxytryptamine hydrochloride (5-MeOT), 5-methoxy-N,N-dimethyltryptamine (5-MeO-N,N-DMT), ( - )-isoprenaline hydrochloride, tryptamine hydrochloride, cocaine hydrochloride, bufotenine monoxalate and parglyine hydrochloride were all purchased from Sigma (UK).

$\alpha$-methyl-5-hydroxytryptamine maleate ( $\alpha$-methyl-5-HT), 2 methyl-5-hydroxytryptamine maleate (2-methyl-5-HT) and tropisetron were obtained from RBI (Natick, MA, U.S.A.) and ascorbic acid from BDH (UK). The following drugs were gifts: $( \pm)$-propranolol hydrochloride from ICI Pharmaceuticals (Macclesfield, Cheshire), BIMU 1 (endo-N-(8methyl-8-azabicyclo[3.2.1]oct-3-yl)-2,3-dihydro-3-ethyl-2-oxo1H-benzimidazole-1-carboxamide hydrochloride), BIMU 8 (endo-N-(8-methyl-8-azabicyclo[3.2.1)oct-3-yl)-2,3-dihydro(1-methyl)ethyl-2-oxo-1H-benzimidazole-1-carboxamide hydrochloride) and DAU 6215 (N-(endo-8-methyl-8-azabicyclo [3.2.1]-oct-3-yl)-2,3-dihydro-2-oxo-1H-benzimidazole-1- carboxamide, hydrochloride) from Istituto de Angeli (Milan, Italy), cisapride from Janssen (Beerse, Belgium), and GR 113808 (([1-[2-[methylsulphonyl amino]ethyl]-4]piperidinyl] methyl 1-methyl-1H-indole-3-carboxylate) from Glaxo Group Research (U.K.). ( - )-and (+ )-zacopride, renzapride hydrochloride, metoclopramide, SB 203186 ((1-piperidinyl)ethyl 1H-indole 3-carboxylate), SDZ 205-557 ((2-diethylaminoethyl)2-methoxy-4-amino-5-chloro-benzoate) and 5-carboxamidotryptamine (5-CT) were synthesized in-house.

All stock solutions were made up in distilled water except tropisetron and cisapride (dimethylsulphoxide), 5-HT and ( - )-isoprenaline $(0.2 \mathrm{mM}$ ascorbate)

\section{Results}

\section{Agonist studies}

Tryptamines The tryptamines 5-HT, 5-MeOT, $\alpha$-methyl5-HT, 5-CT, bufotenine, tryptamine (after pargyline pretreatment), and 5-MeO-N,N-DMT, were all chronotropic agonists in piglet right atrium. Concentration-effect curves to these agonists are shown in Figure 1 and $\mathrm{pEC}_{50}\left(=-\log \mathrm{EC}_{50}\right)$ and intrinsic activity values are displayed in Table 1 . The maximal effect of $5-\mathrm{HT}$ was $72 \%$ of the effect of $200 \mu \mathrm{M}$ isoprenaline. 5-MeOT, $\alpha$-methyl-5-HT, 5-MeO-N,N-DMT and tryptamine were all full agonists relative to 5-HT whilst bufotenine and 5-CT were partial agonists. The 5- $\mathrm{HT}_{3}$ receptor agonist, 2-methyl-5-HT, was a weak partial agonist with a $\mathrm{pEC} \mathrm{C}_{50}$ of $\sim 3.9$ (experiment not shown); its intrinsic activity could not be assessed since it caused depression of heart rate which could not be overcome by 5-HT or isoprenaline.

Concentration-effect curves to 5-HT, 5-CT, 5-MeOT and 5 -MeO- $N, N$-DMT $(n=3)$ were unaffected by treatment of the right atria with the irreversible monoamine oxidase inhibitor, pargyline (not shown) and so pargyline pretreatment was not used in subsequent experiments. Pargyline was used routinely, however, in experiments with tryptamine since no response was obtained when pargyline was absent.

Substituted benzamides The 2-methoxy-4-amino-5-chlorosubstituted benzamides renzapride, cisapride, $(-)$-zacopride, 

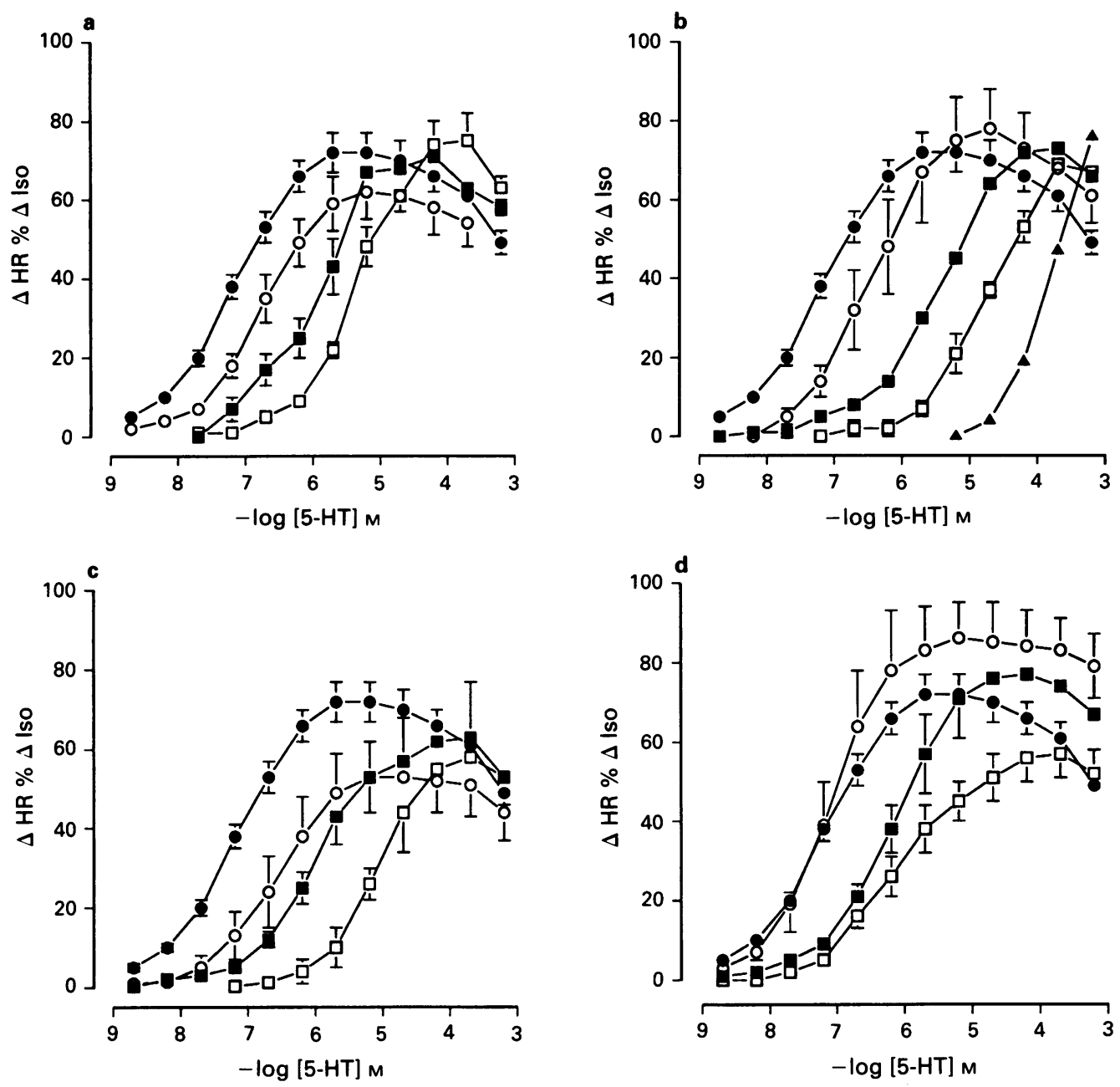

Figure 4 Concentration-effect curves to 5-HT in the absence $(\Theta, n=33)$ and presence of (a) $0.1(O, n=4), 1.0(\mathbb{Q}, n=6)$ and $10 \mu_{\mathrm{M}}(\square, n=5)$ DAU 6215; (b) $0.02(\mathrm{O}, n=3), 0.2(\square, n=2), 2.0(\square, n=3)$ and $10 \mu \mathrm{M}(\Delta, n=2) \mathrm{SB} 203186$; (c) 0.1 (O, $n=5), 1.0(\square, n=4)$ and $10 \mu \mathrm{M}(\square, n=3) \mathrm{SDZ} 205-557$; and (d) $0.002(\mathrm{O}, n=4), 0.01(\square, n=4)$ and $0.1 \mu \mathrm{M}$ GR113808 (口, $n=8)$ in piglet right atrium. Data are means \pm s.e.mean. The chronotropic effects of 5-HT are expressed as percentage of the increase in beating caused by agonist or agonist in the presence of antagonist, plus $200 \mu \mathrm{M}(-)$-isoprenaline $(\Delta \mathrm{HR} \% \Delta$ Iso).

For abbreviations, see text.

Table 2 Binding characteristics and affinity values of antagonists and partial agonists for $5-\mathrm{HT}_{4}$ receptors in piglet right atrium

\begin{tabular}{lccr}
\hline Antagonists & $p \mathrm{~K}_{B}$ or $p \mathrm{~K} p^{a}$ & Slope & $\mathrm{n}$ \\
& & & \\
SB203186 & $8.26 \pm 0.09$ & $0.96 \pm 0.09$ & 10 \\
DAU 6215 & $7.00 \pm 0.10$ & $0.85 \pm 0.12$ & 15 \\
Tropisetron & $6.89 \pm 0.12^{\mathrm{b}}$ & $1.09 \pm 0.30$ & 7 \\
SDZ 205-557 & & $0.58 \pm 0.07$ & 12 \\
GR 113808 & & non-linear & 16 \\
& & & \\
Partial agonists & & $1.08 \pm 0.10$ & 25 \\
BIMU 1 & $7.93 \pm 0.11$ & - & 6 \\
Renzapride & $7.95 \pm 0.13^{\mathrm{c}}$ & - & 4 \\
Metoclopramide & $6.00 \pm 0.5^{\mathrm{c}}$ & &
\end{tabular}

${ }^{\mathrm{a}} \mathrm{p} K_{\mathrm{B}}$ or $\mathrm{p} K \mathrm{p}=-\log$ equilibrium dissociation constants; $K_{\mathrm{B}}$, estimated using equation (1); $K p$, estimated using equation (2).

'Data from Kaumann (1990).

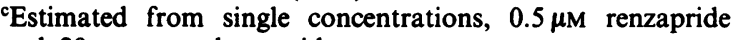
and $20 \mu \mathrm{M}$ metoclopramide.

dMean slope \pm s.e.mean.

$(+)$-zacopride and metoclopramide were less potent agonists than 5-HT in causing tachycardia in piglet right atria (Figure 2). Only ( - )-zacopride was a full agonist with respect to 5-HT. Renzapride was a potent partial agonist (- log
$\mathrm{EC}_{50}=6.7$ ) with an intrinsic activity of 0.7 (with respect to 5-HT), whilst (+)-zacopride, metoclopramide and cisapride were less potent partial agonists and had intrinsic activities of less than 0.4 (Table 1).

Renzapride and metoclopramide antagonized the effects of 5-HT so equilibrium dissociation constants for partial agonists ( $\mathrm{pKp}$ ) were calculated (see below). Above $60 \mu \mathrm{M}$, metoclopramide caused a dramatic decrease in heart rate.

Azabicycloalkyl benzimidazolone derivatives The azabicycloalkyl benzimidazolone derivative BIMU 8 was a potent full agonist relative to $5-\mathrm{HT}$ in piglet right atrium (Figure 3). BIMU 1 was a chronotropic partial agonist of low intrinsic activity (Table 1, Figure 3). BIMU 1 also antagonized the effects of 5-HT, so that a $\mathrm{pKp}$ for partial agonist activity was calculated (see below).

DAU 6215 showed no chronotropic effects with concentrations of up to $60 \mu \mathrm{M}$ (Figure 3) and caused some decrease in heart rate above this concentration. DAU 6215 was also tested for antagonist properties (see below).

\section{Antagonist studies}

Tropisetron $(3 \mu \mathrm{M})$ antagonized the positive chronotropic effects of 5-MeOT $(n=5), \alpha$-methyl-5-HT $(n=4)$ and 5-MeO-N,N-DMT $(n=3)$, the log concentration-ratios being $1.28 \pm 0.30 ; \quad 1.33 \pm 0.17$ and $0.50 \pm 0.30$ respectively. 


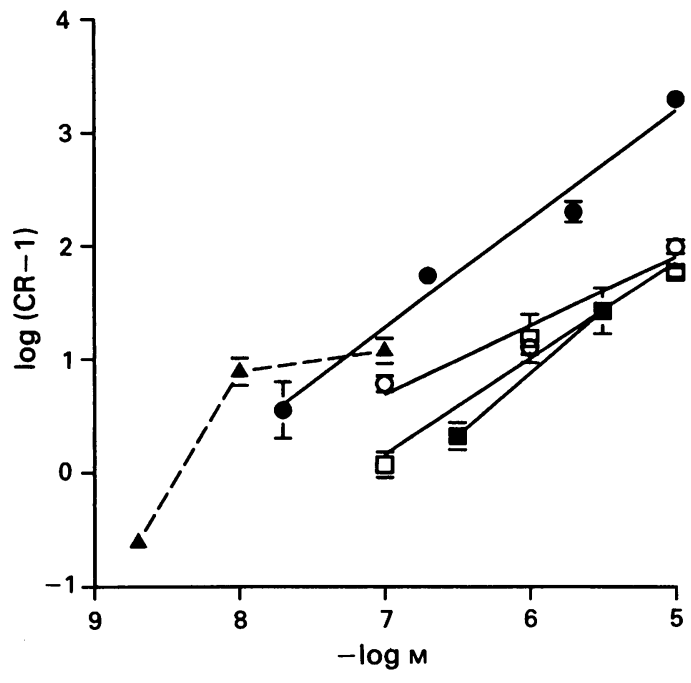

Figure 5 Schild plots from antagonism of 5-HT-induced tachycardia by DAU 6215 (प), SDZ 205-557 (O), SB 203186 (O), GR113808 $(\Delta)$ and tropisetron ( $\square)$ in piglet right atrium. Mean slopes \pm s.e.mean: $0.96 \pm 0.09$ (SB 203186), $0.58 \pm 0.07$ (SDZ 205557), $1.09 \pm 0.3$ (tropisetron) and $0.85 \pm 0.12$ (DAU 6215). A mean slope was not calculated for GR 113808 because the plot was nonlinear.
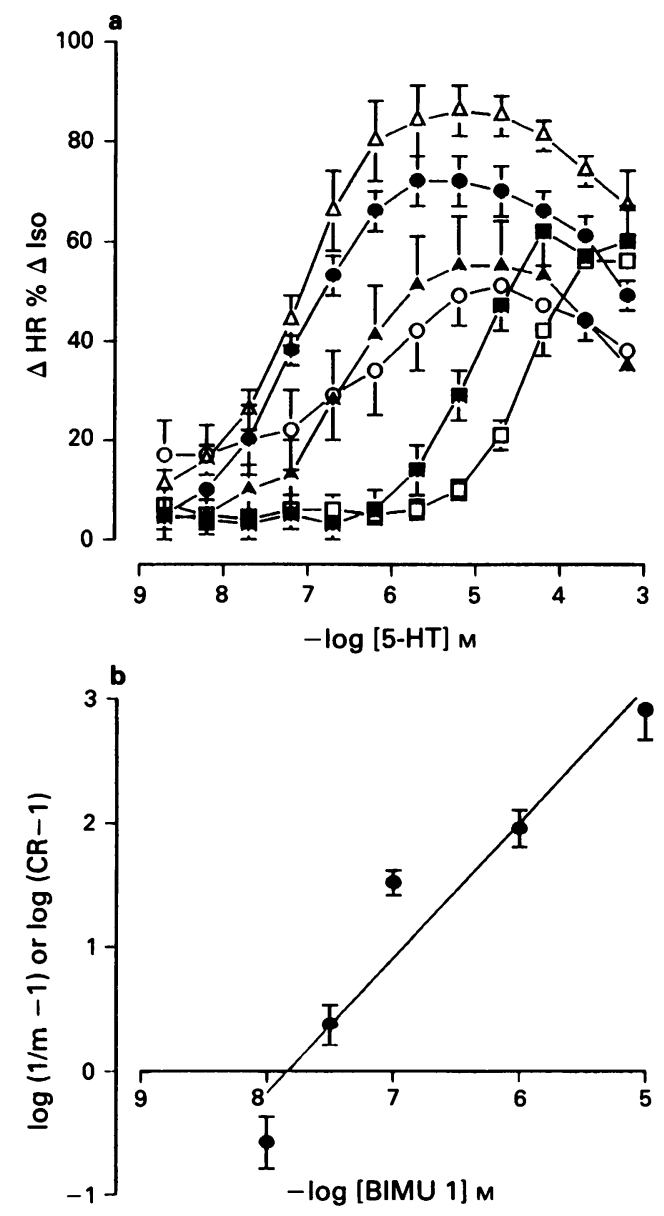

Figure 6 (a) Concentration-effect curves to 5-HT in the absence ( $(\bullet$, $n=33)$ and presence of $0.01(\Delta, n=5), 0.03(\Delta, n=4), 0.1(\mathrm{O}$, $n=5), 1.0(\square, n=6)$ and $10 \mu \mathrm{M}(\square, n=5)$ BIMU 1 in piglet right atrium; data are means \pm s.e.mean, chronotropic effects are expressed as a percentage of the increase in beating caused by agonist alone or in the presence of antagonist, plus $200 \mu \mathrm{M}(-)$-isoprenaline ( $\Delta$ HR \% $\Delta$ Iso). (b) Double log plot for simple competitive inhibition by BIMU 1; data from (a), calculated using equations (1) and (2); mean slope \pm s.e. mean $=1.08 \pm 0.10$.
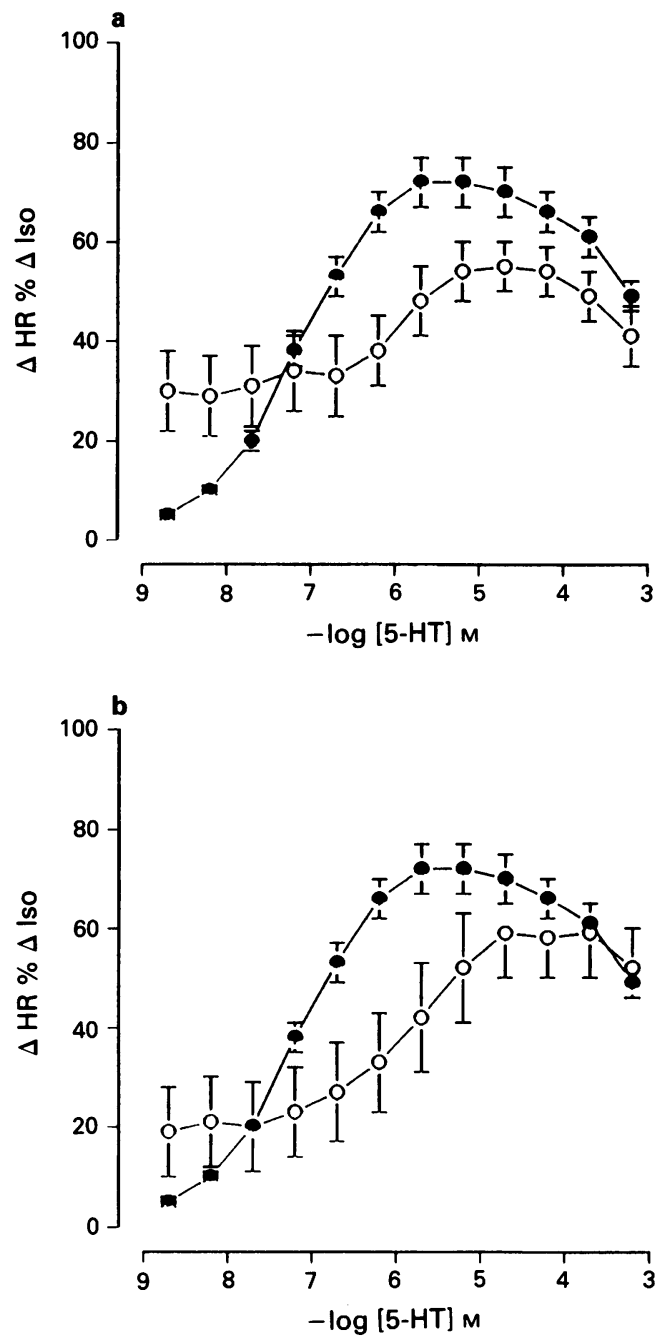

Figure 7 Concentration-effect curves to 5-HT in the absence ( $O$, $n=33)$ and presence of (a) $0.5 \mu \mathrm{M}$ renzapride $(O, n=6)$ and (b) $20 \mu \mathrm{M}$ metoclopramide $(O, n=4)$ in piglet right atrium. Data are means \pm s.e.mean. The chronotropic effects of 5-HT, renzapride and metoclopramide are expressed as a percentage of the increase in beating caused by agonist alone or in the presence of antagonist, plus $200 \mu \mathrm{M}(-)$-isoprenaline $(\Delta \mathrm{HR} \% \Delta$ Iso).

Tropisetron ( $3 \mu \mathrm{M})$ also antagonized BIMU 8-induced increases in heart rate $(n=4)$ but the blockade was partially unsurmountable with up to $60 \mu \mathrm{M}$ BIMU 8 (data not illustrated). Responses to tryptamine $(n=4)$ were completely abolished with $3 \mu \mathrm{M}$ tropisetron (not shown).

DAU $6215(0.1-10 \mu \mathrm{M})$ and SB $203186(0.02-10 \mu \mathrm{M})$ caused parallel rightward shifts of concentration-effect curves to 5-HT (Figure 4a and b). The slopes of the Schild regression were not significantly different from unity and yielded estimated $\mathrm{p} K_{\mathrm{B}}$ values of 7.0 and 8.3 respectively (Figure 5, Table 2). SDZ 205-557 (0.10-10 $\mu \mathrm{M})$ also caused rightward displacement of the 5-HT curve (Figure 4c) but the slope of the Schild regression was only 0.58 (Figure 5) so a meaningful estimate of $\mathrm{p} K_{\mathrm{B}}$ for SDZ 205-557 could not be made. Similarly, a meaningful $\mathrm{p} K_{\mathrm{B}}$ estimate for GR 113808 could not be made because although 0.01 and $0.1 \mu \mathrm{M}$ shifted the 5-HT curve to the right, $0.1 \mu \mathrm{M}$ also tended to reduce the maximum response to 5-HT and did not produce a significantly greater shift than $0.01 \mu \mathrm{M}$ (Figure 4d). Since $0.002 \mu \mathrm{M}$ GR 113808 only caused marginal blockade and because of the lack of concentration-dependent antagonism with 0.01 and $0.1 \mu \mathrm{M}$, the resultant Schild plot was non-linear (Figure 5). 

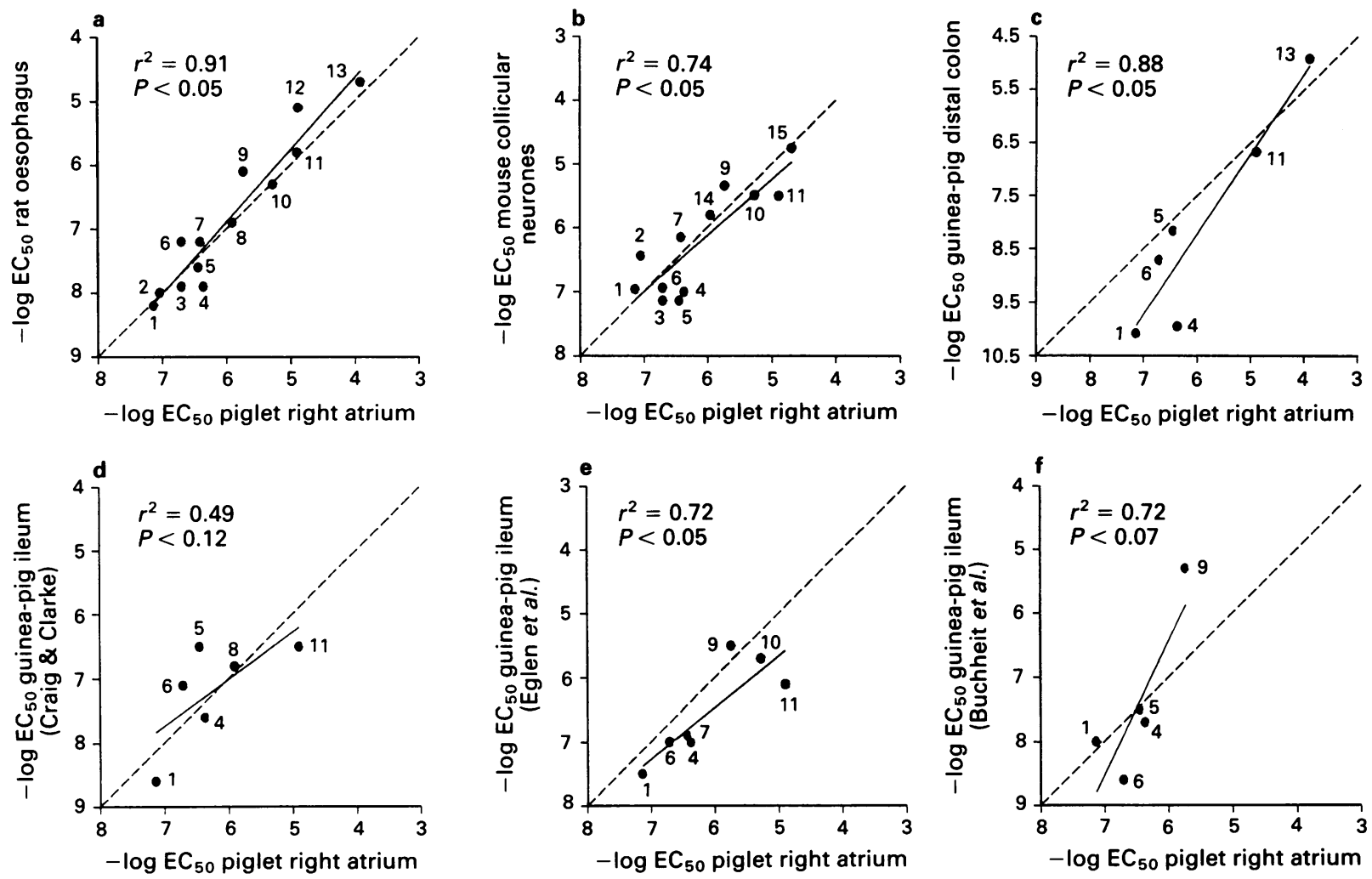

Figure 8 Squared correlation coefficients $\left(r^{2}\right)$ and regression lines for 5-HT 4 receptor agonists in piglet right atrium and (a) rat oesophagus (Baxter et al., 1991, Baxter \& Clarke, 1992); (b) mouse embryonic colliculi neurones (Dumuis et al., 1988; 1989; 1991); (c) guinea-pig distal colon (Wardle \& Sanger, 1992); (d), (e) and (f) guinea-pig ileum (Craig \& Clarke, 1990; Eglen et al., 1990; Buchheit \& Buhl, 1991, respectively); (1) 5-HT; (2) BIMU 1; (3) BIMU 8; (4) 5-MeOT; (5) cisapride; (6) renzapride; (7) ( - )-zacopride, (8) $\alpha$-methyl-5-HT; (9) metoclopramide; (10) (+ )-zacopride; (11) 5-CT; (12) tryptamine; (13) 2-methyl-5-HT; (14) bufotenine, and (15), 5-MeO- $N, N$-DMT. For abbreviations, see text.

\section{Partial agonist studies}

BIMU 1 (Figure 6), renzapride $(0.5 \mu \mathrm{M})$ and metoclopramide $(20 \mu \mathrm{M})$ (Figure 7) also shifted 5-HT concentration-effect curves to the right. Since they had some agonist activity $\mathrm{pKp}$ values were estimated with equation (2) (Lemoine \& Kaumann, 1982) although in some experiments, where they caused little or marginal stimulation, affinity values were estimated with equation (1) (Arunlakshana \& Schild, 1959). The slope of the double log plot for BIMU 1 according to equations (1) and (2) was not significantly different from unity (Figure 6). The estimated $\mathrm{p} K \mathrm{p}$ value for BIMU 1 was 7.9 (Table 2). pKp values were 7.9 for renzapride and 6.0 for metoclopramide as estimated from single concentrations (Table 2).

\section{Discussion}

The aim of our study was to compare piglet sinoatrial $5-\mathrm{HT}_{4}$ receptors (Kaumann, 1990) with $5-\mathrm{HT}_{4}$ receptors in other peripheral tissues and CNS. To exclude 5-HT 4 receptorunrelated factors that determine agonist potency we used cocaine (which blocks tissue uptake of 5-HT thereby making more 5-HT available to the receptors, Kaumann et al., 1990) and propranolol (which blocks $\beta$-adrenoceptors thereby preventing possible action of released noradrenaline, Kaumann, 1990). In some cases we also blocked monoamine oxidase (MAO)

The irreversible MAO inhibitor, pargyline, did not alter 5-HT-evoked responses which is consistent with the observations of Baxter et al. (1991). The responses to 5-MeOT, 5-CT and $5-\mathrm{MeO}-\mathrm{N}, \mathrm{N}-\mathrm{DMT}$ were also unaffected by pargyline. Conversely, no chronotropic responses were obtained with tryptamine unless pargyline was present, indicating a particular susceptibility of tryptamine to deamination by MAO. A similar effect of MAO inhibition was observed with tryptamine interacting with $5-\mathrm{HT}_{2}$ receptors of bovine large coronary artery (Frenken \& Kaumann, 1988) indicating that the enzyme avidly oxidizes tryptamine in the neighbourhood of more than one class of 5-HT receptors.

$\mathrm{pEC}_{50}$ values were determined for tryptamine, benzamide and benzimidazolone derivatives for comparison with those obtained in rat oesophagus (Baxter et al., 1991; Baxter \& Clarke, 1992), guinea-pig ileum and colon (Craig \& Clarke, 1990; Eglen et al., 1990; Buchheit \& Buhl, 1991; Wardle \& Sanger, 1992) and mouse embryonic colliculi neurones (Dumuis et al., 1988; 1989; 1991) (Figure 8). We assessed agonist potency in absolute terms as $\mathrm{pEC}_{50}$ values. This seemed the most relevant method of potency determination for this study, because the data we were using for comparison from other studies also used $\mathrm{pEC}_{50}$ values as a measure of agonist potency. Figure 8 shows there is excellent correlation between potency estimates for agonists in piglet atria and those in rat oesophagus and guinea-pig distal colon although the number of compounds compared is small for the latter. A weaker but still reasonable correlation is seen with piglet sinoatrial $5-\mathrm{HT}_{4}$ receptors and $5-\mathrm{HT}_{4}$ receptors in mouse embryonic colliculi neurones. There is borderline correlation between our data and the guinea-pig ileum data of Eglen et al. (1990) and Buchheit \& Buhl (1991) whilst a poor correlation is seen with the data of Craig \& Clarke (1990). This probably reflects a small sample size or that one drug is an outlier.

The relatively low stimulant potency of tryptamines and benzamides in piglet atria (Figure 8) suggests a relatively low 5-HT $\mathrm{H}_{4}$ receptor reserve or alternatively deficient coupling to biochemical effectors compared to guinea-pig ileum (Craig \& 
Clarke, 1990; Buchleit \& Buhl, 1991) and distal colon (Wardle \& Sanger, 1992) or rat oesophagus (Baxter et al., 1991). The advent of a suitable $5-\mathrm{HT}_{4}$ receptor radioligand may reveal variations in $5-\mathrm{HT}_{4}$ receptor reserve in the different tissues. Indeed, preliminary autoradiographic studies with the novel 5-HT ${ }_{4}$ receptor radioligand, $\left[{ }^{3} \mathrm{H}\right]-\mathrm{GR} 113808$, have revealed variations in specific binding to different brain regions of the rat and guinea-pig (Grossman et al., 1993).

A number of tryptamine derivatives are full or partial agonists at $5-\mathrm{HT}_{4}$ receptors in the CNS (Dumuis et al., 1988), gut (Craig \& Clarke, 1990; Baxter et al., 1991; Wardle \& Sanger, 1992) and heart (Kaumann, 1990; Kaumann et al., 1990; 1991a,b; Villalon et al., 1990; 1991). We obtained the following order of potency for chronotropic activity: 5HT $>5$-MeOT $>\alpha$-methyl-5-HT $=$ bufotenine $>5-\mathrm{CT}=$ tryptamine (after pargyline pretreatment) $>5-\mathrm{MeO}-N, N$-DMT $>$ 2-methyl-5-HT. All tryptamines tested were full agonists compared to 5-HT except 5-CT, bufotenine and 2-methyl-5HT.

Benzamides are key ligands for $5-\mathrm{HT}_{4}$ receptor characterization since they are more selective agonists than the tryptamines (although they can antagonize $5-\mathrm{HT}_{3}$ receptors). These compounds are usually partial agonists at $5-\mathrm{HT}_{4}$ receptors (Kaumann, 1990; Kaumann et al., 1991a,b; Baxter et al., 1991; Villalon et al., 1990; 1991) although in mouse embryonic colliculi neurones their intrinsic activity often exceeds that of 5-HT (Dumuis et al., 1989). Results from this study and of Kaumann (1990) in piglet right atria show that benzamides are partial agonists with low intrinsic activity except for ( - -zacopride which was a full agonist relative to 5-HT. The order of potency for these agents was renzapride $>$ cisapride $=(-)$-zacopride $>$ metoclopramide $>(+)$-zacopride. The similarity of the eudismic ratio for zacopride is consistent with similar steric configurations of the $5-\mathrm{HT}_{4}$ receptors in piglet, guinea-pig and rat. The stereoselectivity of the $5-\mathrm{HT}_{4}$ receptor to isomers of zacopride with a 10 fold potency separation between $(-)$-zacopride $\left(\mathrm{pEC}_{50}=6.41\right)$ and $(+)$-zacopride $\left(\mathrm{pEC}_{50}=5.27\right)$, is also a feature previously described in rat oesophagus (Baxter et al., 1991) and guinea-pig ileum (Eglen et al., 1990).

Because benzamides were partial agonists in piglet right atria, affinity estimates for renzapride and metoclopramide were obtained from experiments investigating antagonism of the chronotropic effects of 5-HT. The affinity estimate for renzapride $(\mathrm{p} K \mathrm{p}=7.9)$ was greater than its stimulant potency estimate $\left(\mathrm{pEC}_{50}=6.7\right)$ suggesting desensitization of $5-\mathrm{HT}_{4}$ receptors in addition to competition for the receptors. High renzapride concentrations have previously been shown to desensitize 5- $\mathrm{HT}_{4}$ receptors (Dumuis et al., 1989; Kaumann, 1990). In contrast, the affinity estimate for metoclopramide was similar to its potency estimate suggesting lack of desensitization and supporting the observations of Bockaert et al. (1992b) who showed desensitization with renzapride but not with metoclopramide. They proposed that $5-\mathrm{HT}_{4}$ receptor desensitization was proportional to agonist affinity.

Azabicycloalkyl benzimidazolones have also proved to be useful ligands for characterizing 5- $\mathrm{HT}_{4}$ receptors (reviewed by Turconi et al., 1991). BIMU 8 and BIMU 1 are potent full or partial agonists at the 5- $\mathrm{HT}_{4}$ receptor in mouse colliculi (Dumuis et al., 1991), rat oesophagus (Baxter \& Clarke, 1992), and guinea-pig ileum (Rizzi et al., 1992). Similarly, in the present study with piglet atria, BIMU 8 was a full agonist whilst BIMU 1 was a partial agonist relative to 5-HT. BIMU 1 was similar in potency to 5-HT but more potent than BIMU 8 as determined from the corresponding $\mathrm{pEC}_{50}$ values. We obtained an affinity estimate from experiments where the 5-HT concentration-effect curve was shifted to the right by BIMU 1. As with renzapride, desensitization seemed to be present since the affinity estimate $\left(\mathrm{p} K_{\mathrm{p}} \simeq 7.9\right)$ for BIMU 1 was greater than the potency estimate $\left(\mathrm{pEC}_{50} \simeq 7.1\right)$, and at high concentrations fade of the BIMU 1-induced responses occurred.

Another benzimidazolone derivative, DAU 6215 was reported to be a weak partial agonist in mouse embryonic colliculi neurones (Dumuis et al., 1991) but a competitive antagonist in rat oesophagus (Baxter \& Clarke, 1992). In piglet right atria we found no chronotropic activity with DAU 6215 which at high concentrations even decreased the heart rate. DAU 6215 behaved as a simple competitive antagonist at sinoatrial $5-\mathrm{HT}_{4}$ receptors with a $\mathrm{p} K_{\mathrm{B}}$ of 7.1 yielded from the Schild plot. This figure compared favourably with a $\mathrm{pA}_{2}$ value of 6.7 in rat oesophagus (Baxter \& Clarke, 1992), but was rather higher than the value of 5.5 estimated in mouse embryonic colliculi neurones by Dumuis et al. (1991).

Buchheit et al. (1992) recently introduced SDZ 205-557 as a 30 fold $5-\mathrm{HT}_{4}$ receptor selective (compared to $5-\mathrm{HT}_{3}$ ) antagonist of 5-HT-evoked contractions in guinea-pig ileum with an affinity of 7.4 whilst Eglen et al. (1991) showed that SDZ 205-557 had a $\mathrm{p} K_{\mathrm{B}}$ of 7.1 in rat oesophagus. In piglet right atria SDZ 205-557 also antagonized 5-HT-induced tachycardia but this antagonism did not appear to be simple competitive. This may partially reflect a non-specific effect of this drug. We were unable to calculate a meaningful $\mathrm{p} K_{\mathrm{B}}$ estimate since the slope of the Schild plot was 0.58

GR113808 was recently presented as a novel $5-\mathrm{HT}_{4}$ receptor antagonist with a $\mathrm{pA}_{2}$ of 9.2 and 9.5 in guinea-pig colon and rat oesophagus respectively (Grossman et al., 1993). On piglet atrium, 2 nM GR113808 caused marginal blockade (Figures 4d and 5) and appeared to be less potent than on gut (Grossman et al., 1993). In the present study we were unable to obtain a $\mathrm{p} K_{\mathrm{B}}$ estimate since the Schild plot slope was non-linear, suggesting that the blockade was not simple competitive. There was a reduction in the maximum response to 5-HT with $0.1 \mu \mathrm{M}$ GR113808 in our experiments, a phenomenon reported in the guinea-pig colon at the same concentration (Grossman et al., 1993). This suggests a nonspecific effect of GR 113808 in these systems. The novel selective 5-HT ${ }_{4}$ receptor blocker SB 203186 (Kaumann et al., 1992) was the most potent competitive antagonist investigated in the present study. We obtained a $\mathrm{p} K_{\mathrm{B}}$ of 8.3 for SB 203186, 20 fold or more potent than tropisetron and DAU 6215. Similar affinity estimates for SB 203186 have been obtained in piglet left atrium and human atrial strips (Parker et al., 1993) where 5- $\mathrm{HT}_{4}$ receptors have also been demonstrated (Kaumann et al., 1990; 1991a,b).

In conclusion, we have shown that $5-\mathrm{HT}_{4}$ receptors in piglet right atria are sensitive to the three groups of agonists used to characterize this receptor, as well as being blocked by a number of antagonists reported to be selective for 5-HT receptors in the literature. We suggest that piglet sinoatrial $5-\mathrm{HT}_{4}$ receptors are similar to $5-\mathrm{HT}_{4}$ receptors of rat oesophagus, guinea-pig ileum and colon, mouse embryonic colliculi neurones and human atrium.

\section{References}

ARUNLAKSHANA, O \& SCHILD, H.O. (1959). Some quantitative uses of drug antagonism. Br. J. Pharmacol. Chemother., 14, 48-58. BAXTER, G.S. \& CLARKE, D.E. (1992). Benzimidazolone derivatives act as 5- $\mathrm{HT}_{4}$ receptor ligands in rat oesophagus. Eur. J. Pharmacol., 212, 225-229.
BAXTER, G.S., CRAIG, D.A. \& CLARKE, D.E. (1991). 5Hydroxytryptamine $_{4}$ receptors mediate relaxation of rat oesophageal tunica muscularis mucosae. Naunyn-Schmied. Arch. Pharmacol., 343, 439-446. 
BLINKS, J.R. (1956). Positive chronotropic effect of increasing right atrial pressure in the isolated mammalian heart. Am. J. Physiol., 186, 299-303.

BLINKS, J.R. (1965). Convenient apparatus for recording contractions of isolated muscle. J. Appl. Physiol., 20, 755-757.

BOCKAERT, J., ANSANAY, M., SEBBEN, M., FAGIN, L. \& DUMUIS, A. (1992b). Characterisation of homologous $5-\mathrm{HT}_{4}$ receptor desensitisation in colliculi neurons. Proceedings 2nd International Symposium on Serotonin from Cell Biology to Pharmacology and Therapeutics, Houston (USA), Sept 15-18, p. 30. Kluwers Academic Publishers.

BOCKAERT, J., FOZARD, J.R., DUMUIS, A. \& CLARKE, D.E. (1992a). The 5- $\mathrm{HT}_{4}$ receptor: a place in the sun. Trends Pharmacol Sci., 13, $141-145$.

BUCHHEIT, K.-H. \& BERTHOLET, A. (1992). 5-HT effects on isolated strips from guinea-pig stomach. Naunyn-Schmied. Arch. Pharmacol., 345, R111, 442.

BUCHHEIT, K.-H. \& BUHL, T. (1991). Prokinetic benzamides stimulate peristaltic activity in the isolated guinea-pig ileum by activation of 5-HT 4 receptors. Eur. J. Pharmacol., 205, 203-208.

BUCHHEIT, K.-H., GMASE, R. \& PFANNKUCHE, H.-J. (1991). SDZ 205-557, a selective antagonist at 5- $\mathrm{HT}_{4}$ receptors in the isolated guinea-pig ileum. Eur. J. Pharmacol., 200, 373-374.

BUCHHEIT, K.-H., GMASE, R. \& PFANNKUCHE, H.-J. (1992). SDZ 205-557, a selective, surmountable antagonist for 5-HT 4 receptors in the isolated guinea-pig ileum. Naunyn-Schmied. Arch. Pharmacol., 345, 387-393.

CRAIG, D.A. \& CLARKE, D.E. (1990). Pharmacological characterisation of a neuronal receptor for 5-hydroxytryptamine in guineapig ileum with properties similar to the 5-hydroxytryptamine receptor. J. Pharmacol. Exp. Ther., 252, 1378-1386.

DUMUIS, A., BOUHELAL, R., SEBBEN, M., CORY, R. \& BOCKAERT, J. (1988). A non-classical 5-hydroxytryptamine receptor positively coupled with adenylate cyclase in the central nervous system. Mol. Pharmacol., 34, 880-887.

DUMUIS, A., SEBBEN, M. \& BOCKAERT, J. (1989). The gastrointestinal prokinetic benzamide derivatives are agonists at the nonclassical $5-\mathrm{HT}$ receptor $\left(5-\mathrm{HT}_{4}\right)$ positively coupled to adenylate cyclase in neurones. Naunyn-Schmied. Arch. Pharmacol., 340, 403-410.

DUMUIS, A., SEBBEN, M., MONFERINI, E., NICOLA, M., TURCONI M., LADINSKY, H. \& BOCKAERT, J. (1991). Azabicycloalkyl benzimidazolone derivatives as a novel class of potent agonists at the $5-\mathrm{HT}_{4}$ receptor positively coupled to adenylate cyclase in brain. Naunyn-Schmied. Arch. Pharmacol., 343, 245-251.

EGLEN, R.M., ALVAREZ, R., WONG, E.H.F., JOHNSON, L., PERKINS L.A., RAMSEY, S., LOURY, D.N., TANG, H.-M., WALLACE, S. \& WHITING, R.L. (1992). Characterisation of the interaction of SDZ 205-557 at putative 5- $\mathrm{HT}_{4}$ receptors. Br. J. Pharmacol., 105, 275P.

EGLEN, R.M., SWANK, S.R., WALSH, L.K.M. \& WHITING, R.L. (1990). Characterisation of 5- $\mathrm{HT}_{3}$ and 'atypical' 5-HT receptors mediating guinea-pig ileal contractions in vitro. Br. J. Pharmacol., 101, 513-520.

ELSWOOD, C.J., BUNCE, K.T. \& HUMPHREY, P.P.A. (1991) Identification of putative 5- $\mathrm{HT}_{4}$ receptors in guinea-pig ascending colon. Eur. J. Pharmacol., 196, 149-155.

FORD, A.P.D.W., BAXTER, G.S., EGLEN, R.M. \& CLARKE, D.E (1992). 5-hydroxytryptamine stimulates cyclic AMP formation in the tunica muscularis mucosae of the rat oesophagus via 5-HT receptors. Eur. J. Pharmacol., 211, 117-120.

FRENKEN, M. \& KAUMANN, A.J. (1988). Effects of tryptamine mediated through 2 states of the $5-\mathrm{HT}_{2}$ receptor in calf coronary artery. Naunyn-Schmied. Arch. Pharmacol., 337, 484-492.

GROSSMAN, C.J., GALE, J.D., BUNCE, K.T., KILPATRICK, G.J., WHITEHEAD, J.W.F., OXFORD, A.W. \& HUMPHREY, P.P.A (1993). Development of a radioligand binding assay for the 5- $\mathrm{HT}_{4}$ receptor: use of a novel antagonist. $\mathrm{Br}$. J. Pharmacol., 108, $106 \mathrm{P}$
KAUMANN, A.J. (1990). Piglet sinoatrial 5-HT receptors resemble human atrial 5- $\mathrm{HT}_{4}$-like receptors. Naunyn-Schmied. Arch. Pharmacol., 342, 619-622.

KAUMANN, A.J., BROWN, A.M. \& RAVAL, P. (1991b). Putative 5- $\mathrm{HT}_{4}$-like receptors in piglet left atrium. Br. J. Pharmacol., 102, 98P.

KAUMANN, A.J., MEDHURST, A.D., BOYLAND, P., VIMAL, M. \& YOUNG, R.C. (1992). SB 203186, a potent selective 5-HT 4 receptor antagonist. Proceedings 2nd International Symposium on Serotonin from Cell Biology to Pharmacology and Therapeutics, Houston (U.S.A.), Sept 15-18, p. 44. Kluwers Academic Publishers.

KAUMANN, A.J., MCINERNY, T.K, GILMOUR, D.P. \& BLINKS, J.R (1980). Comparative assessment of $\beta$-adrenoceptor blocking agents as simple competitive antagonists in isolated heart muscle: similarity of inotropic and chronotropic blocking potency against isoproterenol. Naunyn-Schmied. Arch. Pharmacol., 311, 219-236.

KAUMANN, A.J., SANDERS, L., BROWN, A.M., MURRAY, K.J. \& BROWN, M.J. (1990). A 5-hydroxytryptamine receptor in human atrium. Br. J. Pharmacol., 100, 879-885.

KAUMANN, A.J., SANDERS, L., BROWN, A.M., MURRAY, K.J. \& BROWN, M.J. (1991a). A 5-HT - -like receptor in human right atrium. Naunyn-Schmied. Arch. Pharmacol., 344, 150-159.

LEMOINE, H. \& KAUMANN, A.J. (1982). A novel analysis of concentration-dependence of partial agonism. Naunyn-Schmied. Arch. Pharmacol., 320, 130-144.

MARANO, M. \& KAUMANN, A.J. (1976). On the statistics of drugreceptor constants for partial agonists. J. Pharmacol. Exp. Ther., 198, 518-525

PARKER, S.G., HAMBURGER, S., TAYLOR, E.M. \& KAUMANN, A.J. (1993). SB 203186, a potent $5-\mathrm{HT}_{4}$ receptor antagonist, in porcine sinoatrial node and human and porcine atrium.Br. J. Pharmacol. 108, 68P.

REEVES, J.J., BUNCE, K.T. \& HUMPHREY, P.P.A. (1991). Investigation into the 5-hydroxytryptamine receptor mediating smooth muscle relaxation in rat oesophagus. Br. J. Pharmacol., 103, $1067-1072$.

RIZZI, C.A., COCCINI, T., ONORI, L., MANZO, L. \& TONINI, M (1992). Benzimidazolone derivatives: a new class of 5-hydroxytryptamine $_{4}$ receptor agonists with prokinetic and acetylcholine releasing properties in the guinea-pig ileum. J. Pharmacol. Exp. Ther., 261, 412-419.

SANDERS, L. \& KAUMANN, A.J. (1992). A 5-HT 4 -like receptor in human left atrium. Naunyn-Schmied. Arch. Pharmacol., 345, $382-386$

SHENKER, A., MAAYANI, S., WEINSTEIN, H. \& GREEN, J.P. (1987). Pharmacological characterisation of two 5-hydroxytryptamine receptors coupled to adenylate cyclase in guinea-pig hippocampal membranes. Mol. Pharmacol., 31, 357-367.

TURCONI, M., SCHIANTARELLI, P., BORSINI, F., RIZZI, C.A. LADINSKY, H. \& DONETTI, A. (1991). Azabicycloalkyl benzimidazolones: Interaction with serotonergic $5-\mathrm{HT}_{3}$ and $5-\mathrm{HT}_{4}$ receptors and potential therapeutic implications. Drugs of the Future, 16, 1011-1026.

VILLALON, C.M. DEN BOER, M.O., HEILIGERS, J.A.C. \& SAXENA P.R. (1990). Mediation of 5-hydroxytryptamine-induced tachycardia in the pig by the putative $5-\mathrm{HT}_{4}$ receptor. Br. J. Pharmacol., 100, 665-667.

VILLALON, C.M., DEN BOER, M.O., HEILIGERS, J.A.C. \& SAXENA, P.R. (1991). Further characterisation, by use of tryptamine and benzamide derivatives, of the putative $5-\mathrm{HT}_{4}$ receptor mediating tachycardia in the pig. Br. J. Pharmacol., 102, 107-112.

WARDLE, K. \& SANGER, G. (1992). Guinea-pig distal colon: a sensitive model of the putative $5-\mathrm{HT}_{4}$ receptor. $\mathrm{Br}$. J. Pharmacol., 105, 279P. 